\title{
BYZANTIUM, RUS AND CUMANS IN THE EARLY 13TH CENTURY*
}

\author{
ALEXANDER V. MAIOROV \\ Department of Museology, St. Petersburg State University \\ Universitetskaia Naberezhnaia, 7/9, St. Petersburg, 199034, Russia \\ e-mail: a.v.maiorov@gmail.com
}

This paper examines the foreign policy of the Galician-Volhynian prince Roman Mstislavich. Roman became the main military ally of the Byzantine Empire in the early 13th century. Byzantium was going through a severe political crisis caused by the Serbian and the Bulgarian uprisings and by the crushing raids of the Cumans. According to Niketas Choniates, the nomads' aggression could have been stopped only thanks to the aid of the Galician prince Roman. The circumstances and the time of Roman's campaign in Choniates' account are the same as in the Russian chronicles reporting the steppe campaigns of the Galician-Volhynian prince.

Key words: Roman Mstislavich, Emperor Alexios III, Rus', Byzantium, Cumans.

All the Byzantine sources name Galician-Volhynian Prince Roman Mstislavich

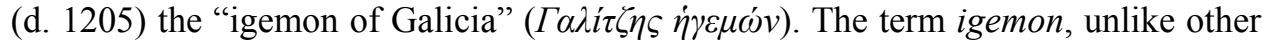
Byzantine titles of Russian princes, meant the Emperor's ally and relative (or in-law) (see Maiorov 2015a, pp. 272-303). The military aid that Roman rendered to Emperor Alexios III was guaranteed by Roman's marriage to the niece of Alexios III, the elder daughter of the overthrown emperor Isaak II (see Maiorov 2014, pp. 188-233). The alliance between Rus' and Byzantium, founded by Roman, retained its value at least until the mid-13th century (Maiorov 2015b, pp. 11-34; cf. also Maiorov 2015c, pp. 345-366).

For several years Prince Roman rendered military assistance to the Empire in its struggle with the Danube Cumans who took the side of the rebellious Bulgarians. Due to the victorious campaigns of the Russian armed forces, the Cumans ceased their attacks against the Empire.

* This study was carried out with the financial support of the Russian Science Foundation (Rossiiskii nauchnyi fond), Project 16-18-10137. 
In their predicament, the Byzantines perceived the assistance rendered by Roman Mstislavich - who quickly assembled "a brave and numerous armed force", attacked the Cumans and devastated their lands - as a miracle, and as "protection sent down by God". Niketas Choniates describes this event with the following enthusiastic report about the Rus' prince and "the most Christian people of Rus" ":

"It was Roman, the Prince of Halych, who quickly assembled a brave and numerous armed force, attacked the Cumans and, having passed through their land without stopping, plundered and devastated it. After repeating such attacks several times to the glory and the magnificence of the holy Christian faith, the smallest part of which like, for example, a mustard seed, can shift mountains and move rocks, he stopped the raids of the Cumans and put an end to those terrible miseries that the Romans suffered from them. In this way he rendered to the people of the same faith an unexpected assistance, an unforeseen defense and, so to say, protection sent down by God." (Nicetas Choniates, pp. 522-523)

Thus, as we have seen, Roman helped Byzantium by repeatedly taking the field against the Cumans. According to Niketas Choniates, the prince of Rus' began warfare against the inhabitants of the steppe regions at the direct request of the Empire

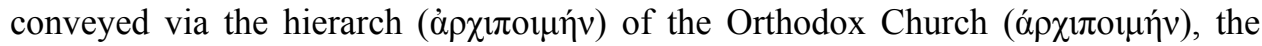
Patriarch of Constantinople or the Metropolitan of Kiev. Moreover, Roman participated in the conflict with Bulgaria on the side of Byzantium. This also helped to stabilise the political position of the Empire in the Balkans. Historians rightly observe that the Galician-Volhynian prince remained almost the only ally of the Byzantine Empire in the period when it underwent its most severe trials, after the alliance of the countries that were loyal to it, had practically ceased to exist (Brand 1968, p. 132; Obolensky 1998, p. 248; Vásáry 2005, pp. 48-49).

Roman Mstislavich will provide military assistance to Byzantium until the capture of Constantinople by the Crusaders, to be more exact until the escape from the besieged capital of Emperor Alexios III. According to The History by Jan Długosz and the Hustynian Chronicle, the overthrown Byzantine Emperor Alexios spent some time in Halych in 1203 after his flight from Constantinople where he met Roman (see Długosz, Annales, Vols 5-6, p. 177; Hustynskaia letopis', p. 108). This fact is confirmed by the Italian chronicler of the late 13 th - early 14th centuries Bartolomeo del Fiadoni (Ptolemy da Lucca) (see Tholomeus Lucensis, pp. 509-510).

Fiadoni, who was born c. 1227, could speak directly to the participants of those events. Being a librarian at the court of John XXII, he was well informed of the foreign policy of the Pope and highly interested in the details of the Fourth Crusade. Besides, for many years Fiadoni was the bishop of Torcello, the island and the town in the Venetian Lagoon, the citizens of which, together with the Venetians, participated in the conquest of Constantinople. The presently known story of the exile of Alexios III, his visit to Bulgaria and the negotiation with Tsar (Emperor) Kaloyan, also testify to the possibility of contacts between the ex-emperor and the GalicianVolhynian prince (see Maiorov 2016, pp. 343-376). 


\section{The Dating of Niketas Choniates' Report on the Campaign of the Galician Prince against the Cumans}

In 1965 N. F. Kotliar suggested that Roman Mstislavich had evidently campaigned against the Cumans for the first time in 1197/1198 (Kotliar 1965, pp. 119-120; see also Kotliar 1989, p. 46; 1991, p. 25). The historian relied on the above report by Niketas Choniates concerning Roman's attack against the inhabitants of the steppe regions, made at the direct request of the Byzantines. As Choniates in his narration did not date the described events, the only evidence allowing us to date the report on the Galician-Volhynian prince's march into the steppe is its initial phrase: "The following year...".

The account concerning Roman in Choniates' History is preceded by the report on the visit of the sultan of Iconium, Kaykhusraw (1192-1196, 1205-1211), to the Byzantine emperor Alexios III (Niketas Choniates, pp. 520-522). Following Kotliar's logic, if one establishes the date of that visit, and adds one year to it, one can obtain the required date of Roman's march into the steppe. The first period of Kaykhusraw's reign ended in 1196, therefore, Kotliar concludes that Roman's campaign against the Cumans took place in 1197 or at the latest in 1198, if one adds time for the exile's travels (Kotliar 2003, p. 88).

Kotliar's reasoning does not account for the fact that the exile of Kaykhusraw lasted over five years - from 1196 until 1205. During this period the ex-sultan visited the Byzantine capital more than once. Moreover, according to Choniates' report, Emperor Alexios received Kaykhusraw not once (as Kotliar believes), but twice.

The first reception took place immediately after the sultan's expulsion, i.e. about 1196 (however, according to some data, the expulsion of Kaykhusraw should be dated to 1197). ${ }^{1}$ At that time, as Choniates reports, Kaykhusraw "received very little sympathy which did not meet his expectations at all" (Niketas Choniates, p. 520). One of the reasons why Alexios III was so cool towards the sultan was, undoubtedly, the episode, also described by Nicetas Choniates, concerning Kaykhusraw's capture of the two Arab stallions that the sultan of Egypt had sent to the Emperor (Niketas Choniates, pp. 493-494).

Failing to obtain support in Constantinople, Kaykhusraw tried to return to Iconium, but was exiled once again and escaped to Armenia with his sons. There he attempted in vain to persuade the Cilician king, Levon II (1186/1187-1219), to render him military assistance. After being refused, the sultan headed for Aleppo in Syria, where he spent about two years. Then he returned to Constantinople for the second time (Niketas Choniates, pp. 520-522; cf. Ibn Bibi, pp. 21-27; see also Cahen 1968, p. 115). Kaykhusraw succeeded in obtaining an audience with the emperor only after a few years of travel. Even so, he failed once again to get military assistance but was able to develop friendlier relations with Alexios. According to George Akropolites, the emperor favoured the ex-sultan so much that he even had him baptised and

\footnotetext{
${ }^{1}$ For various dates of this event, see Gordlevskii (1941, pp. 185-186); Moravcsik (1983, Vol. 2, pp. 57, 112).
} 
adopted him. Later, during the siege of Constantinople by crusaders, we learn that the ex-sultan helped Alexios to escape (Georgios Acropolites, pp. 14-15).

It is clear that when Niketas Choniates described Kaykhusraw's audience with Alexios III before reporting the campaign of Roman Mstislavich against the Cumans, he referred to the second audience rather than to the first one. This is evident from the general order of events and the composition of the account concerning Kaykhusraw's tribulations. After the historian began recounting the second audience with the emperor ("At about that time the satrap of Iconium, Kaykhusraw, presented himself to the emperor"), he described earlier events: "I wish to say a few words about the family of this Persian and I will make a small digression here in order to return later to the sequence of my story." After this aside Niketas Choniates gives a detailed account of how Kaykhusraw was deprived of power and mentions his first meeting with the emperor. Then he dwells on the outcast's escape to Armenia and his return to Constantinople (Niketas Choniates, pp. 520-522).

The second audience of Kaykhusraw with Emperor Alexios can indeed be taken as evidence for dating Roman Mstislavich's campaign against the Cumans. Namely, it could have taken place no earlier than 1200 , i.e. during the second stay of the exsultan in Constantinople that, according to various sources, lasted from 1199/1200 until 1203 (see Ibn Bibi, pp. 27-29; see also Turan 1953, p. 79).

Such dating is completely in line with the general chronology and the sequence of events described by Niketas Choniates at the beginning of his third book of The History devoted to Alexios III's reign. The book begins with the detailed description of Alexios' campaign against the rebel Dobromir Chrysos and the failed siege of his capital Prosek by the Byzantines (Nicetas Choniates, pp. 502-508). ${ }^{2}$ These events, as well as the peace concluded with Chrysos and his marriage with the emperor's family member are usually dated to 1197-1198 (Istoriia na B'lgariia, Vol. 3 (1982), pp. 131-133; Fine 1994, p. 30). Next Choniates reports on the second marriages of Alexios III's daughters Anna and Irina, who married Theodore Laskaris and Alexios Palaeologus, respectively (Niketas Choniates, pp. 508-510). The weddings took place at the very beginning of 1199 (Vannier 1986, p. 164, No. 29 and pp. 170-172).

After that the historian begins recounting in detail Alexios' struggle with a rebel called Ivanko who was the cousin of the Asen brothers (Niketas Choniates, pp. 510-520). In 1196 he headed the conspiracy against Tsar Ivan I and killed him. After the murder of the Bulgarian tsar, Ivanko fled to Constantinople where the emperor made him the ruler of Philippopolis (Plovdiv) and the surrounding regions - the last Byzantine stronghold in rebellious Bulgaria. However, at the end of 1198 Ivanko revolted against the Empire and declared himself an independent ruler (TsankovaPetkova 1978, pp. 42-43; Bozhilov 1985, pp. 44-45).

Troops led by Protostrator Manuel Kamytzes were sent to suppress the uprising. At first, the Byzantines were able to gain some success, but in 1199 Kamytzes

\footnotetext{
${ }^{2}$ About Dobromir Chrysos and its relations with Byzantium see Brand (1968, pp. 128-129, 133-135); Hoffmann (1974, pp. 46-47, 89 ff); Fine (1994, pp. 28-32).
} 
was ambushed and taken prisoner. After that Alexios III himself took over command of the army. The campaign had limited success until, finally, Alexios was able to entrap and kill Ivanko by means of a ruse, namely, by pretending that he wanted to conduct peace negotiations. Historians date the end of this struggle to 1200 (see Zlatarski 1994, Vol. 3, pp. 117-119, 137-139; Fine 1994, pp. 30-31).

After the report on the emperor's return to the capital and a brief account about the eccentric behaviour of Empress Euphrosyne in his absence, Choniates passes on to the above-mentioned audience given by Alexios III to the fugitive sultan of Iconium, Kaykhusraw. According to the historiographer it took place "at about that time", i.e. in the same year 1200 .

Immediately after that report, Choniates places the account of Roman Mstislavich's campaign against the Cumans made at the request of Byzantium in "the following year". Therefore, the campaign should be dated to early 1201 .

Practically all the historians who studied Choniates' report dated Roman's military expedition into Cumania to late 1200 or early 1201 (Hrushevs'ky 1905, p. 561; Levchenko 1956, p. 496; Frances 1959, p. 62; Brand 1968, p. 132; Litavrin 1972, p. 48; Obolensky 1973, p. 204; Istoriia na B"lgariia, Vol. 3, p. 132; Fine 1994, pp. 31-32; Vásáry 2005, pp. 48-49). This is in keeping with the reports on the beginning of the massed attacks on the territory of the empire by the Cumans and the Bulgarians (Scythians and Wallachians), given by Choniates in the end of the second book and the beginning of the third book of his History of Alexios Angelos' reign. The first report describes the barbarian invasion into Thrace, when the cities around Mesina and Churul (Tsiml) were plundered; the second report describes an attack on a larger scale of the lands of Macedonia ("their invasion was greater and more terrible than all the previous ones") (Niketas Choniates, pp. 499-501, 508). Both cases date back to the period from the spring (April) until the fall of 1199 (see Grabler 1958, pp. 7173, 80; Vásáry 2005, pp. 47-48).

Another even more ruinous attack of the Cumans against Byzantium occurred when, according to Choniates, the invaders would have approached the very gate of Constantinople but for Roman Mstislavich's impetuous raid against the enemy's rear (Niketas Choniates, p. 522), evidently took place in the fall-winter of 1200/1201 or the early spring of 1201 (Vásáry 2005, p. 48).

\section{Rus' Sources on the Time of Roman's Campaign against the Cumans}

There can be no doubt that Roman's campaign against the Cumans, described by Choniates, dates to the time when Roman had already become the Galician prince,

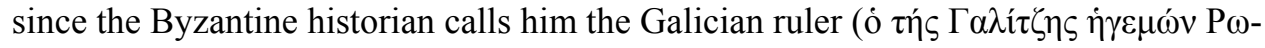

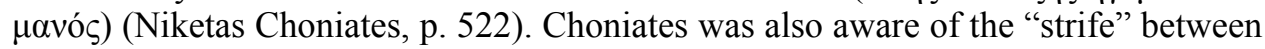
Roman and Rurik, in which Roman won the victory because he was "stronger and more skilful". The historian speaks of this "strife" as an event that took place at the 


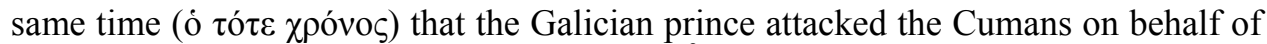
Byzantium (Niketas Choniates, pp. 522-523). ${ }^{3}$

The Russian chronicles date the beginning of Rurik's military activities against Roman and the first seizure of Kiev by the Galician prince to 1202 (Lavrentevskaia letopis', cols 417-418; Voskresenskaia letopis', p. 107). In early 1203 Rurik, with the help of the allied Cumans (with "the whole Cuman land"), recaptured the Kievan throne after devastating the capital of Southern Rus' (Lavrent'evskaia letopis', col. 419; Novgorodskaia Pervaia letopis', pp. 45, 240). Roman and Rurik's joint campaign against the Cumans probably took place at the beginning of the same year 1203 (according to the chronology of the First Novgorod Chronicle), after which Roman attacked Rurik, captured him together with all his family and forced him to become a monk (Lavrent'evskaia letopis', col. 420; Novgorodskaia Pervaia letopis', p. 240).

Obviously, those are the events referred to by Choniates when he speaks of the "strife" that existed between the Kievan and the Galician princes, ending in the victory of the latter. Therefore, Roman Mstislavich's campaigns against the Cumans that stopped their raids on Byzantium must have taken place at about the same time.

According to Niketas Choniates there were only a few campaigns. The historian says that Roman repeated "such attacks" "several times". This fact is also supported by the Russian chronicles that speak about two marches into the steppe, undertaken by the Galician-Volhynian prince with the support of other princes.

The Laurentian chronicle reports on the first campaign. "The same winter Roman went against the Cumans and the whole Cuman land and brought numerous captives and captured many Christian souls from them. And there was a great joy in the land of Rus"' (Lavrent'evskaia letopis', col. 418). The second campaign was evidently on a larger scale: besides Roman, the Kievan prince Rurik Rostislavich, the Pereiaslavlian prince Iaroslav Vsevolodovich (the son of Vsevolod the Big Nest) and "other princes" participated (Lavrent'evskaia letopis', col. 420). This campaign is also known from the report of the younger version of the First Novgorod chronicle, where a certain prince Mstislav is listed among the participants (Novgorodskaia Pervaia letopis', p. 240).

The dating of the campaigns creates a number of difficulties concerning the chronology of the early 13 th-century reports in the Laurentian chronicle, the main source of information for the subject of our research. The entry referring to Roman's first campaign against the Cumans is at the very end of the account dedicated to the year 6710. As N. G. Berezhkov has established, in this account the chronicler used the Ultra-March style of year denotation. The Ultra-March year 6710 corresponds to the March year 6709 that, translated into the Christian calendar, lasts from 1 March 1201 until 28 February 1202 (Berezhkov 1963, pp. 86-87).

The historian pays special attention to the second half of the account concerning events in Southern Rus', in particular to Roman Mstislavich's campaign against the Cumans. He compares it to the account reported by Niketas Choniates concerning the Galician prince's campaign into the Cuman lands that stopped the Cumans' raids

\footnotetext{
${ }^{3}$ Researchers dated the news year 1202: Grabler (1958, p. 95).
} 
into Byzantium. Having studied the chronology of the preceding and subsequent reports in Choniates' History, N. G. Berezhkov arrived at the correct conclusion that Roman's campaign against the Cumans described by the historian must have taken place in the first half of September, 6709 (that corresponds to the second half of March, 6708), i.e. to the winter of 1200/1201 (Berezhkov 1963, pp. 86-87).

M. S. Hrushevs'ky (1905, p. 561) came to the same conclusion. In his opinion, Choniates' report describing Roman's campaign against the Cumans should be dated to the winter 1200/1201, while the reports of the Laurentian chronicle and of later chronicles on the Galician-Volhynian prince's first march into the steppe should be dated to the winter of 1201/1202. Hrushevs'ky (1905, p. 561) does not see any need to reconcile the discrepancies in the dating of the campaign.

N. G. Berezhkov adopted a more definite solution. He believed it possible to date the whole group of reports on Southern Rus' in the second part of the account under the year 6710 in the Laurentian chronicle to March, 6708 which month lasted from 1 March 1200 until 28 February 1201. Thus, the historian admits that this account has a complicated chronological composition. First, it includes the reports of the March of the year 6709, and second, it includes the reports of the preceding March of the year 6708 (Berezhkov 1963, p. 87).

As we can see, the Russian chronicles and Choniates leave open the possibility that Roman's first campaign into the steppe can be dated either to late 1200 or to early 1201, while there is no possibility to date it to an earlier period. As for N. F. Kotliar's suggestion that Roman's first campaign can be dated to $1197 / 1198$, it is not supported by Russian or Byzantine sources and should be rejected as erroneous.

Dating the beginning of Roman Mstislavich's military activities against the Cumans at the request of the rulers of the Byzantine Empire to the late 1200 or early 1201 is in line with the evidence of another Old Rus' source. According to the report of a Novgorodian pilgrim Dobrynia Iadreikovich (the future archbishop Antony), an embassy of the Galician-Volhynian Prince Roman Mstislavich visited Constantinople in May, 1200. The Novgorodian pilgrim describes a religious miracle witnessed by him - the rising of burning thuribles in Hagia Sophia - and notes its exact date and the people who saw the miracle with him:

"This miracle was truly revealed by the holy God in the year 6708, during my lifetime, in the month of May, in memory of the holy Tsar Konstantin and his mother Elena, on the 21 st, on a weekday, during the reign of Alexios and the patriarchate of John, on the Synaxis of the Holy Fathers 318, in the presence of the embassy of Tverdiatina Ostromiritsa, who had come with the embassy from the Grand Prince Roman with Nedan and Domazhir, and with Dmitrii and Negvar, the ambassador". (Puteshestvie Antoniia, cols 88-89)

The aim of the embassy, evidently, was to negotiate possible military assistance for the empire in the struggle against the Cumans. Apparently at the same time the embassy arranged the marriage of the Galician-Volhynian prince with a Byzantine princess in order to strengthen the new military and political alliance. This marriage was 
probably concluded immediately, even before the end of 1200 , since we are told that in the following year (1201) Roman had a son with his new Byzantine wife. This is confirmed by the report of the Galician-Volhynian chronicle which states that in the year of Roman's death (1205) his elder son Daniel was four years old (Ipat'evskaia letopis', col. 717).

\section{The Chronology of the Second Campaign against the Cumans in the Russian Chronicles and in the Works of Modern Researchers}

The winter campaign of 1200/1201 was followed by a new campaign of Roman Mstislavich against the Cumans, in which the prince of Kiev, the prince of Pereiaslavl' and other princes participated. This campaign was recorded in the Laurentian Chronicle and in later related chronicles, as well as in the Younger Version of the First Novgorod Chronicle. It is assumed that the Laurentian Chronicle dates this campaign to the year 6713 (1205), while the Younger Version of the First Novgorod chronicle to 6711 (1203) (Lavrent'evskaia letopis', col. 420; Novgorodskaia Pervaia letopis', p. 240). The later Voskresenskii and Nikon Chronicles also date the campaign to 6711 (1203) (Voskresenskaia letopis', p. 108; Nikonovskaia letopis', p. 36).

Researchers focus their attention on the Laurentian Chronicle as the most authoritative source that contains clear and detailed information on the new campaign, and on the subsequent conflict between the Kievan prince Rurik Rostislavich and the Galician-Volhynian prince Roman Mstislavich. After the princes returned with great spoils of war, they gathered for a council in the town of Trypillia near Kiev, where they tried to agree on a new distribution of regions among themselves based on how much effort each of them had expended towards protecting the Russian land from the enemies ("who suffered to what extent for the Russian land"). A disagreement arose and resulted in Roman Mstislavich dethroning Rurik Rostislavich and forcing him to become a monk. Roman also made Rurik's wife and daughter (who used to be Roman's wife) take the veil and took Rurik's two sons, Rostislav and Vladimir, to Halych by force. The prince of Vladimir and Suzdal', Vsevolod the Big Nest, interfered and made Roman release Rurik's sons from captivity. The elder son Rostislav, Vsevolod's son-in-law, became the new prince of Kiev (Lavrent'evskaia letopis', cols 420-421).

The dating of the described events (6713) is not reliable and, as we have seen, differs by several years from the dating of the Younger Version of the First Novgorod Chronicle and other chronicles. This difference can be explained by the lacuna in the protograph of the Laurentian Chronicle. Apparently several parts were missing, thus the pages that contained part of the account under the year 6711, the whole account under 6712, and most of the account under 6713 (Luria 1987a, p. 241).

Being aware of this defect, modern scholars refuse to accept the Laurentian Chronicle's chronology of the events in Southern Rus'. At the same time, they reject the chronology of the First Novgorodian, the Voskresensii and the Nikon Chronicles. Ultimately, historians ascertained the date of the new campaign of the Russian princes against the Cumans and the subsequent dismissal of Rurik Rostislavich from the 
Kievan throne by deriving the arithmetic average of the two dates recorded in different sources.

This is the approach that N. F. Kotliar uses to calculate the date of the Russian princes' campaign against the Cumans: "In the winter of 1204 (in 1203, according to the Voskresenskii Chronicle, in 1205, according to the Laurentian Chronicle), the Russian princes made a great and victorious campaign in the Cuman steppe" (Kotliar 2003, p. 266). M. S. Hrushevs'ky adopted the same approach. However, his knowledge of sources was markedly greater and included chronicles that modern authors do not normally take into consideration: "This report [on the second campaign of the Russian princes against the Cumans $-A$. M.] is placed under the year 1205 in the Laur[entian] [Chronicle], under 1204 - in the Gust[yna] and the Tversk[aia] [Chronicles], under 1203 - in the Voskr[esenskii] and the Nikon [Chronicles]; the date of the Hust[ynian] [Chronicle] seems the most probable" (Hrushevs'ky 1891, p. 267, n. 1). It is unlikely that Hrushevs'ky preferred the Hustynian Chronicle because he considered it the most trustworthy. Rather, the year 1204 seemed to be the most probable to the historian as an average value between the two extremes. In our opinion, this is a naïve way of solving historical chronology problems.

M. S. Hrushevs'ky revised his position after addressing the problems of the chronology of the second campaign of the Russian princes against the Cumans and that of the subsequent events once again. As far as we know, his attempt to determine the date of the campaign remains the only one in scholarly literature; unfortunately, it also failed. Showing a preference for the chronology of the First Novgorod Chronicle, Hrushevs'ky (1905, p. 228, n. 1) pessimistically concluded: "it appears impossible to find a plausible date".

Owing to the uncertainty of the chronology of the second campaign against the Cumans, modern investigators report it under various dates. B. A. Rybakov (1993, p. 495) dated the campaign to 1203 . J. Fennell $(1989$, p. 65) dated it to the late winter of 1203 or the early spring of 1204 . Some modern authors prefer the chronology of the Laurentian Chronicle and even quote its reports regarding the campaign and its prehistory. Thus, A. P. Tolochko (2005, p. 289) wrote: "From the entry in the Laur[entian chronicle] under the year 1204 we learn that Roman negotiated with Vsevolod Iur'evich about the Olgovichi ... In 1205, old offences, apparently, were forgotten for the time being, as Roman together with Rurik set out on a major campaign against the Cumans".

As we see, the issue of the dating of the Russian princes' campaign against the Cumans and the associated events in the Southern Rus' requires further research.

\section{The Contents of the Chronicle Reports Concerning the Campaign against the Cumans}

As the Kievan Chronicle reports ceased in 1200, and the initial part of the GalicianVolhynian Chronicle was lost, the events of 1201-1205 in Southern Rus' are known mainly from the reports of the Vladimir-Suzdal' and the Moscow Chronicles, supplemented in some cases by the Novgorodian reports. 
The data concerning the second campaign of the Russian princes against the Cumans and the events preceding and following the campaign are contained in a number of surviving records of North-Eastern Rus' from the late 14th-15th centuries that go back to three chronicles of the first half of the 13th century. The existence of these chronicles is ascertained by historians. They include the chronicle of 1205 (reproduced in the Radziwiłł Chronicle and the Chronicle of Pereiaslavl' Suzdal'skii), the chronicle of Konstantin Vsevolodovich of 1217 (reproduced in the Laurentian Chronicle, the Troitskii and the Simeon Chronicles) and the chronicle of Iurii Vsevolodovich of 1238 (reproduced in the Moscow Svod of the late 15th century [the Moscow Grand Princely Svod of 1479] and in the Ermolinskii Chronicle). ${ }^{4}$ While the Troitskii and the Simeon Chronicles, as well as the Grand Princely Svod of 1479 and the Ermolinskii Chronicle, place the report about the campaign under the year 6711 (Troitskaia letopis', pp. 286-287; Simeonovskaia letopis', pp. 38-39; Moskovskii Letopisnyi Svod konca XV veka, pp. 100-101; Ermolinskaia letopis', pp. 58-59), the Radziwiłł Chronicle and the Chronicle of Pereiaslavl' Suzdal'skii date it to 6713 (Radzivilovskaia letopis', p. 161; Letopisets Pereiaslavlia Suzdal'skogo, pp. 124-126).

Sources such as the Radziwiłł Chronicle and the Chronicle of Pereiaslavl' Suzdal'skii were the basis for the chronicle of 1518 which survives as parts of the L'vov Chronicle and the Tver' Chronicle (Shakhmatov 1902, pp. 46-51; Shakhmatov 1904, pp. 33-48; see also Miliutenko 1996, pp. 38 ff). The last two confuse the events in the entries under the years 6711-6714. This is also characteristic of the Radziwiłł Chronicle and the Chronicle of Pereiaslavl' Suzdal'skii (L'vovskaia letopis', pp. 142-143; Rogozhskii letopisets, cols 292-294). The Troitskii Chronicle, known mainly from the extracts made by N. M. Karamzin, was the source of the All-Russian Chronicle of 1418 that is reproduced in the First Sophia and the Fourth Novgorod Chronicles (Nasonov 1969, pp. 205-206, 262-270). They contain information, close to that of the Troitskii Chronicle, about the events in Southern Rus' dated to 67116713 (Novgorodskaia Chetvertaia letopis', p. 180).

However, the Laurentian Chronicle - the most important source that is so eagerly referred to by modern authors - has to be excluded from this extensive list of sources that have data concerning the second campaign of the Russian princes against the Cumans. This chronicle - the only one from among those listed above - cannot be used in the investigation of the mentioned campaign. The problem is that this earliest surviving chronological record of North-East Rus' did not contain any reference to the second campaign of the princes against the Cumans.

In the Laurentian Chronicle published under the editorship of E. F. Karsii in the first volume of the Complete Collection of Russian Chronicles, the missing text of the report on the campaign is reproduced from other sources, namely, from the

\footnotetext{
${ }^{4}$ See also Shakhmatov (1902, pp. 59-67) and Priselkov (1996, pp. 101-103). Of the most recent studies, see Miliutenko (1996, pp. 36-58) (here the earlier literature on the question).
} 
Radziwiłł Chronicle (the Radziwiłł copy of the late 15th century) and the Moscow Academic Chronicle, that was compiled at the turn of the 15th-16th centuries and still remains unpublished (Russian State Library, F. 173/1, No. 236). ${ }^{5}$

However, this decision of the publishers of the Laurentian Chronicle cannot be considered legitimate. Moreover, using extracts from other chronicles, close as they might be but not identical with the Laurentian Chronicle, instead of the missing original text of the source can only mislead the reader.

A. A. Shakhmatov was the first to observe that the Radziwiłł Chronicle and the Chronicle of Pereiaslavl' Suzdal'skii possess a number of individual features that contrast them with all the other northeastern chronicles. These features consist mainly in their systematic emphasis and underscoring in every way of the role of the prince of Vladimir and Suzdal' Vsevolod the Big Nest (Bol'shoe Gnezdo) in the politically significant events of the second half of the 12th-early 13th centuries. Similar accounts given by other chronicles do not contain this feature (Shakhmatov 1902, pp. 33-35, 86-91; 1938, pp. 11-12, 47-48, 52-54). This observation by Shakhmatov was supported and further developed by M. D. Priselkov and other scholars (Priselkov 1996, pp. 84-108; Luria 1987c, pp. 65-66; Miliutenko 1996, p. 37).

N. I. Miliutenko compared the text at the end of the entry under the year 6713 surviving in the Laurentian Chronicle with the corresponding text of the Simeon Chronicle. He pointed out that both sources are identical but they differ from the Radziwiłł Chronicle and the Chronicle of Pereiaslavl' Suzdal'skii (Miliutenko 1996, pp. 39-40, 48, Table 1). In our opinion, Miliutenko came to the plausible conclusion that in order to fill the gap in the Laurentian Chronicle regarding the years 67116713, one should use the text of the Simeon Chronicle, and where the specific references of N. M. Karamzin are found, to use the text of the Troitskii Chronicle (Miliutenko 1996, p. 40).

In most surviving chronicles, and above all in those reproducing the chronicles of Konstantin Vsevolodovich (1217) and Yurii Vsevolodovich (1238), the events connected with the second campaign of the Russian princes against the Cumans are given in one chronicle entry under the year 6711 . This does not apply to the Radziwiłł Chronicle and the Chronicle of Pereiaslavl' Suzdal'skii that reproduce the chronicle of 1205 where the account of the events in question was divided into several parts in entries under 6712-6713.

\footnotetext{
${ }^{5}$ Publishers specifically inform in the footnotes on the use of the Radziwiłł and the Moscow Academic Chronicles' texts instead of the lost text of the Laurentian Chronicle; see Lavrent'evskaia letopis', col. 418 , n. $\partial$; col. 423 , n. 8 .
} 


\section{The Troitsky and the \\ Simeon Chronicles}

Under the year 6711
The Radziwitt Chronicle and the

Chronicle of Pereiaslavl' Suzdal'skii

Under the year 6712

At the request of Roman Mstislavich, the At the request of Roman Mstislavich, the ambassador of Grand Prince Vsevolod the ambassador of Grand Prince Vsevolod the Big Nest, Mikhail Borisovich, places un- Big Nest, Mikhail Borisovich, places under oath the Olgovichi princes, while the der oath the Olgovichi princes, while the Olgovichi place under oath Vsevolod and Olgovichi place under oath Vsevolod and Roman.

Roman.

The heavenly sign of January 22 - the appearance of four suns and one moon.

Under 6713

The victorious campaign of the Russian The victorious campaign of the Russian princes - Rurik of Kiev, Iaroslav of Pere- princes - Rurik of Kiev, Iaroslav of Pereiaslavl', Roman of Halych, etc. - against iaslavl', Roman of Halych, etc. - against the Cumans, the capture of rich loot. the Cumans, the capture of rich loot.

The council of princes in Trypillia and The council of princes in Trypillia and their attempt to conclude an agreement on their attempt to conclude an agreement on the regions (riad o volostiakh). The con- the regions (riad o volostiakh). The conflict between Roman and Rurik; Rurik is flict between Roman and Rurik; Rurik is deprived of the Kievan throne and forced deprived of the Kievan throne and forced to take monastic vows together with his to take monastic vows together with his wife and daughter; Roman captures $\mathrm{Ru}$ - wife and daughter; Roman captures $\mathrm{Ru}$ rik's sons. rik's sons.

Clashes between the Olgovichi and Lithuania.

The embassy of Vsevolod the Big Nest to Halych demanding that Roman release The embassy of Vsevolod the Big Nest to Rurik's sons, Rostislav and Vladimir. RoHalych demanding that Roman release man meets the demand. Rostislav occupies Rurik's sons, Rostislav and Vladimir. Ro- the Kievan throne.

man meets the demand. Rostislav occupies the Kievan throne.

Clashes between the Olgovichi and Lithuania.

The difference between the two groups of sources can be seen in the previous entry that is different in both contents and chronology. 


\section{The Troitsky and the \\ Simeon Chronicles}

Under 6710

Taking and plundering of Kiev by Rurik, the Olgovichi and the Cumans on January 2 .

The description of the plundering that Kiev suffered.

Rostislav Iaroslavich, the prince of Snov, captures Mstislav Vladimirovich.

Roman Mstislavich and Rurik Rostislavich conclude peace at Vruchii on February 16 . Rurik swears allegiance to Vsevolod the Big Nest and to his sons Konstantin and Yurii.

At Rurik and Roman's request, Vsevolod gives the Kievan throne to Rurik.
The Radziwitt Chronicle and the

Chronicle of Pereiaslavl' Suzdal'skii

Under 6711

Taking and plundering of Kiev by Rurik, the Olgovichi and the Cumans on January 2 .

The description of the plundering that Kiev suffered.

Rostislav Yaroslavich, the prince of Snov, captures Mstislav Vladimirovich.

Heavenly signs

Roman Mstislavich and Rurik Rostislavich conclude peace at Vruchii on February 16. Rurik swears allegiance to Vsevolod the Big Nest and to his sons Konstantin and Yuri.

At Rurik and Roman's request, Vsevolod gives the Kievan throne to Rurik.

The entry under the year 6711 of the Laurentian Chronicle (only the beginning of the entry survived, namely, the report on taking and plundering Kiev by Rurik and his allies) coincides with the chronology of the Radziwiłł Chronicle and the Chronicle of Pereiaslavl' Suzdal'skii. However, the contents of the Laurentian Chronicle for the period between the late 12 th -early 13 th centuries, on the whole, are closer to the Troitskii and the Simeon Chronicles.

Therefore, it is possible that the account of the events connected with the second campaign of the Rus' princes against the Cumans in the Laurentian Chronicle, similarly to the Troitskii and the Simeon Chronicles, was given in a one year entry. In the Troitskii and the Simeon Chronicles, the mentioned events are given in the entry under the year 6711. As the chronology of the Laurentian Chronicle in the reports concerning the early 13 th century is systematically ahead by one year, the events in question in the lost original text were evidently given in the entry under 6712.

Now let us try to determine the date of the campaign and the Southern Rus' events connected to it, according to the Gregorian calendar. 


\section{The Leonides of 18 October 1202}

As we could see, the chronology of the accounts of the Laurentian Chronicle concerning the early 13th century, especially the chronology of the Southern Rus' reports contained therein, is complicated, and creates many difficulties for researchers.

The entry under the year 6711 in the Laurentian Chronicle begins with the report concerning the seizure of Kiev by Rurik Rostislavich, who had only recently been forced by Roman to cede the Kievan throne to Roman's protégé, the prince of Lutsk, Igor (Ingvar) Iaroslavich. Rurik won Kiev back with the help of the Olgovichi, the princes of Chernigov, and of "all the Cuman land" on January 2, "the day of Saint Pope Sylvester" (Lavrent'evskaia letopis', col. 418).

Both the Older and the Younger Versions of the First Novgorod Chronicle cite a different day for the capture of Kiev - "the 1st day of January, the feast of St Basil" (Novgorodskaia Pervaia letopis', pp. 45, 240). Apparently, the struggle for Kiev was fierce and lasted for at least two days. It is probable that some chronicles date the seizure of Kiev to the day when the attackers burst into the city, while others consider it to be the day when the last pockets of resistance were suppressed (Berezhkov 1963, p. 315, n. 84$)$.

The description of the subsequent cruel plundering of the capital of Southern Rus' in the Laurentian Chronicle ends with an unfinished phrase: “... have put all that..." (Lavrent'evskaia letopis', col. 418, n. $\partial$ ). The text of the Laurentian Chronicle resumes with the report on the death of Elena, Vsevolod the Big Nest's daughter, dated December 30 (Lavrent'evskaia letopis', col. 421, n. 6). It was mechanically included in the entry under 6711 of the Laurentian Chronicle. In the Chronicle of Pereyaslavl Suzdalsky and in the Moscow Academic Chronicle this report is given in the entry under 6713 (Lavrent'evskaia letopis', col. 421; Letopisets Pereiaslavlia Suzdal'skogo, p. 126), while the Troitskii and the Simeon Chronicles place it at the end of the entry under 6712 (Troitskaia letopis', p. 287; Simeonovskaia letopis', pp. 38-39).

As we have seen, in the edition of the first volume of the Complete Collection of Russian Chronicles, the restored entries of the Laurentian Chronicle for the years 6711, 6712, and early 6713 were based on the texts of the Radziwiłł Chronicle and the Moscow Academic Chronicle. The Chronicle of Pereiaslavl' Suzdal'skii contains the same text. In order to use the text of the Radziwiłł Chronicle, it is necessary to combine the two parts of the entry under the year 6711 . This entry had been divided (in both manuscripts extant today - the Radziwiłł Chronicle and the Academic Chronicle), evidently, due to the confusion in the order of the pages in the original, that is, in the protograph. The end of the entry under the year 6711 , the entry under 6712 and the larger part of the entry under 6713 follow the entry under the year 6714 that ends the chronicle (Shakhmatov 1902, pp. 18-19; 1938, p. 10; Luria 1987b, p. 248).

Following the description of the plunder of Kiev, the entry under the year 6711 in its complete form reports heavenly signs that presaged this misfortune and, therefore, preceded it. In the Radziwiłł Chronicle, as well as in the Chronicle of Pereiaslavl' Suzdal'skii, we read: "That same winter there were many signs in heaven. We will report one of them: one night, at four in the morning, the whole sky poured out [on 
the earth] so that the earth was red as well as the houses and the snow. It seemed to all the people capable of seeing that blood was spilt on the snow. Some saw a stream of stars in the sky; when they fell to the earth, it seemed to the onlookers that death had drawn near" (Radzivilovskaia letopis', p. 161; Letopisets Pereiaslavlia Suzdal'skogo, p. 125).

The first omen mentioned here occurred in the winter. Judging from the chronicle description, it looked like bright flashes in the night sky, casting on the winter snow deep red gleams that resembled the colour of blood. This appears to be a description of the effect of the northern lights (Sviatskii 2007, pp. 263, 279).

To determine the date of the events in question, the report concerning the second omen is of relevance. Its description in the chronicle, according to experts, corresponds to the astronomical phenomenon that occurs at regular intervals and therefore can be dated precisely. It is the Leonides - the meteor shower that appears annually from the direction of the Leo constellation. The shower forms as a result of a substance released by the comet Tempel-Tuttle. This comet approaches the earth's orbit every 33 years. At that time the Leonides can be seen well with the naked eye: the smallest parts of the cosmic substance burn up in the earth's atmosphere and form a star shower that "pours" most powerfully in the initial minutes and gradually weakens (see Fedynsky 1956, pp. 9 ff; Bakulin 1973, pp. 572, 579-580).

The above chronicle extract describes the Leonides observed in the sky over the East European Plain on 18 October 1202 (Sviatskii 2007, p. 237). Therefore, the entry under the year 6711 reports on the omens in reverse order: first, the winter phenomenon of the northern lights, and then the preceding Leonides observed in October. The entry ends with the report of the peace agreement between Roman and Rurik made at Vruchii at the end of the same year, on the sixteenth day of February, and on the decision of the prince of Vladimir and Suzdal', Vsevolod the Big Nest, to give the Kievan throne to Rurik (Radzivilovskaia letopis', p. 161; Letopisets Pereiaslavlia Suzdal'skogo, p. 125).

Thus, the report concerning the Leonides confirms that the entry under 6711 in the Radziwiłł Chronicle and in the Chronicle of Pereiaslavl' Suzdal'skii has the UltraMarch system of dating. Therefore, the events described in this report - the seizure of Kiev and the Vruchii agreement - date to the end of the March year of 6710, i.e. to the winter of 1202/1203 (Berezhkov 1963, p. 87).

The second campaign of the Russian princes against the Cumans took place immediately after the negotiations at Vruchii and the acknowledgement of Rurik's right to the Kievan throne, i.e. soon after 16 February 1203. Based on the above calculations, this campaign should be dated to the late winter or, more likely, to the early spring of 1203. Taking into account the general rule that the princes of Rus' would normally conduct their military expeditions into the Cuman steppe in the early spring, the said campaign must have been made in March 1203. This date is in line with the chronology of the Southern Rus' accounts of the Troitskii and the Simeon Chronicles, as well as those of the First Novgorod Chronicle. They report on the second campaign of the Rus' princes against the Cumans at the beginning of the entry under the March year 6711 (Troitskaia letopis', p. 286; Simeonovskaia letopis', pp. 38-39; Novgorod- 
skaia Pervaia letopis', p. 240); the campaign lasted from 1 March 1203 until 29 February 1204.

The Troitskii and the Simeon Chronicles place the negotiations between Roman and Rurik at Vruchii at the end of the entry under the March year 6710 which ended on 28 February 1203. The negotiations took place on February 16, "on the feast day of the Martyr Pamphilus". The entry of the following year 6711 begins with the report concerning Roman Mstislavich's diplomatic preparation for the new campaign into the steppe. To that end, he evidently needed to settle his relationship with the Olgovichi of Chernigov. At Roman's request, the ambassador of Grand Prince Vsevolod the Big Nest, Mikhail Borisovich, placed the Olgovichi princes under oath, while the Olgovichi, via their ambassadors, placed Vsevolod and Roman under oath.

\section{The Original Composition of the Chronicle Entry on the Campaign against the Cumans and its Subsequent Rearrangement}

For clarifying the chronology of the events given in the entry under 6711 in the Troitskii and Simeon Chronicles, Southern Rus' reports of the Older Version of the First Novgorod Chronicle are important. This version survives in the Synod scroll (The State Historical Museum, Synodical collection, No. 786), which is the oldest of the existing Russian chronicles. Its oldest part, ending in 1234 (ff. $1-118 \mathrm{v}$ ), can be dated to the second half of the 13th century (Kloss-Luria 1976, pp. 80-81; Kloss 2000, p. V).

The Older Version of the First Novgorod Chronicle mentions only two episodes of those enumerated above. They are the seizure and the plunder of Kiev by Rurik and the Cumans on January 1, and the victorious campaign of the Olgovichi princes against Lithuania (Novgorodskaia Pervaia letopis', p. 45). The Novgorodian chronicler for some reason combined these events into one entry (under the March year 6711), having preserved the same sequence for the events as in the Vladimir-Suzdal' chronicles: first, he reports the seizure of Kiev by Rurik, then the campaign of the Olgovichi princes against Lithuania. Since we know exactly that Kiev was seized on 1-2 January 1203, i.e. at the end of March 6710, the campaign of the Olgovichi princes against Lithuania, that took place shortly afterwards, should undoubtedly be dated to the beginning of the following March of the year 6711, i.e., most likely, to the spring months of $1203 .^{6}$

\footnotetext{
${ }^{6}$ The attribution of the campaign of the Olgovichi against Lithuania for $6712(1204 / 1205)$ in the Manuscripts of the Younger version of the First Novgorod Chronicle, as rightly noted by researchers, was caused by the insertion in the original chronicle's text of the Tale on the Taking of Tsargrad by the Crusaders, as a result of which part of the article 6711's text was transferred to the next annual article, see Hrushevs'ky (1905, p. 228, n. 1); Aleshkovskii (1981, pp. 105-106); Nikitin (2005, pp. 428-430); see also Maiorov-Metelkin (2016, pp. 809-820).
} 
Thus, the campaign of the Olgovichi princes against Lithuania roughly coincides with the campaign of other Southern Rus' princes against the Cumans organised by Prince Roman. This fact might explain why the Chernigov princes did not participate in it.

One can agree with N. I. Miliutenko's assumption that the original composition of the entry under the year 6711 was the same as in the Troitsky and the Simeon Chronicles, as well as in the Moscow Grand Princely Svod of the late 15th century and in the Ermolinskii Chronicle, where these events are narrated chronologically. The Radziwiłł Chronicle and the Chronicle of Pereiaslavl' Suzdal'skii reflect the scribe's attempt to rearrange the events thematically: first, they tell everything about Rurik and his family, then continue reporting about the Olgovichi princes. As the end of Rurik' account - the release of his sons from captivity and the granting of the Kievan throne to Rostislav Rurikovich - apparently took place in spring of 1204, the beginning of the account was also dated to 1204 in the Radziwiłł Chronicle and in the Chronicle of Pereiaslavl' Suzdal'skii. Accordingly, the campaign of the Olgovichi princes against Lithuania was dated incorrectly. In reality, it took place in the late winter-early spring of 1203 (Miliutenko 1996, p. 56).

Thus, the second campaign of Roman Mstislavich against the Cumans had to take place in the early spring of 1203, probably in the first half of March when it was still cold. Such weather conditions contributed to the success of the Rus' army and aggravated the position of the Cumans ("the winter was harsh at that time, and great hardships befell the Cumans").

Such dating of the campaign is completely in line with the information given about Roman by the contemporary Byzantine historian Niketas Choniates. Having reported about the first campaign of the Galician-Volhynian prince against the Cumans that took place in early 1201, Choniates says that Roman later repeated "such an attack several times" and thus "stopped the raids of the Cumans" into Byzantium. Roman's new campaign (or campaigns) against the Cumans, according to Choniates, occurred when "strife flared up" between the "Tauro-Scythians" (i.e. the Russians). Roman and "the Kievan ruler" Rurik "stained their swords with the blood of their fellow countrymen". Choniates was aware of the fact that Roman eventually achieved a complete victory over Rurik, "having exterminated a great number of Cumans, who helped Rurik in his struggle and constituted the strongest and the most powerful part of his army" (Niketas Choniates, pp. 522-523).

Obviously, Choniates had in mind the events in Southern Rus' that occurred in 1202-1203 and were connected with the second campaign of the princes of Rus' against the Cumans and the accompanying struggle between Roman and Rurik. The Byzantine historian and courtier could obtain the data on this campaign and on Roman's victory over Rurik only if all those events took place before the beginning of the siege of Constantinople by the crusaders, i.e. before the beginning of July 1203 . It is unlikely that "the strife between the Tauro-Scythians" would have been of interest to the Byzantine nobleman in the period of the enemy's siege and the subsequent fall of the empire's capital. Besides, the campaign against the Cumans, arranged by Roman in the interests of his ally Emperor Alexius III, would have been unnecessary 
early in 1204, when Alexius was deprived of power and exiled. Niketas Choniates was dismissed immediately after the escape of Alexius III (17 July 1203), lost his sources of information, and soon after had to flee from the devastated capital.

\section{Abbreviations}

\section{Russian Sources}

Ermolinskaia letopis’ In: Pokrovsky, F. I. (ed.): Polnoe Sobranie Russkikh Letopisei, Vol. 23. Moscow, 2004.

Hustynskaia letopis’ In: Kuchkin, V. A. (ed.): Polnoe Sobranie Russkikh Letopisei, Vol. 40. St. Petersburg, 2003.

Ipat'evskaia letopis' In: Shakhmatov, A. A. (ed.): Polnoe Sobranie Russkikh Letopisei, Vol. 2. Moscow, 1998.

Lavrent'evskaia letopis' In: Karsky, E. F. (ed.): Polnoe Sobranie Russkikh Letopisei, Vol. 1. Moscow, 1997.

Letopisets Pereiaslavlia Suzdal'skogo In: Buganov, V. I. et al. (eds): Polnoe Sobranie Russkikh Letopisei, Vol. 41. Moscow, 1995.

L'vovskaia letopis' In: Adrianov, S. A. (ed.): Polnoe Sobranie Russkikh Letopisei, Vol. 20. Moscow, 2005.

Moskovskii Letopisnyi Svod konca XV veka In: Tikhomirov, M. N. (ed.): Polnoe Sobranie Russkikh Letopisei, Vol. 25. Moscow, 2004.

Nikonovskaia letopis' In: Bychkov, A. F. (ed.): Polnoe Sobranie Russkikh Letopisei, Vol. 10. Moscow, 2000.

Novgorodskaia Chetvertaia letopis’ In: Pokrovskii, F. I. (ed.): Polnoe Sobranie Russkikh Letopisei, Vol. 4/1. Moscow, 2000.

Novgorodskaia Pervaia letopis' starshego i mladshego izvodov In: Nasonov, A. N. (ed.): Polnoe Sobranie Russkikh Letopisei, Vol. 3. Moscow, 2000.

Puteshestvie Antoniia Savaitov, P. P. (ed.): Puteshestvie novgorodskogo arkhiepiskopa Antoniia $v$ Tsar'grad v kontse 12-go stoletiia. Saint Petersburg, 1872.

Radzivilovskaia letopis' In: Priselkov, M. D. et al. (eds): Polnoe Sobranie Russkikh Letopisei, Vol. 38. Leningrad, 1989.

Rogozhskii letopisets In: Likhachev, N. P. (ed.): Polnoe Sobranie Russkikh Letopisei, Vol. 15. Moscow, 2000.

Simeonovskaia letopis' In: Presniakov, A. E. (ed.): Polnoe Sobranie Russkikh Letopisei, Vol. 18. Moscow, 2007.

Troitskaia letopis' In: Priselkov, M. D. (ed.): Troitskaia letopis'. Rekonstruktsiia teksta. Saint Petersburg, 2002.

Voskresenskaia letopis’ In: Bychkov, A. F. (ed.): Polnoe Sobranie Russkikh Letopisei, Vol. vii. Moscow, 2000.

\section{Greek, Latin and Persian Sources}

Długosz, Annales = Dąbrowski, J. (ed.): Ioannis Dlugosii Annales, seu Cronicae incliti regni Poloniae, Vols 5-6. Warszawa, 1973. 
Georgios Acropolites = Heisenberg, A. - Wirth, P. (eds): Georgii Acropolitae Opera, Vol. 1. Stuttgart, 1978.

Ibn Bibi = Duda, H. W. (ed. and transl.): Die Seltschukengeschichte des Ibn Bibi. Kopenhagen, 1959, pp. 21-27.

Niketas Choniates = van Dieten, I. A. (ed.): Nicetae Choniatae Historia . Berlin-New York, 1975 (Corpus Fontium Historiae Byzantinae, ser. Berolinensis 11/1).

Tholomeus Lucensis = Clavuot, O. - Schmugge, L. (eds): Tholomeus Lucensis Historia ecclesiastica nova. Hannover, 2009 (Monumenta Germaniae Historica, Scriptores 39).

\section{Bibliography}

Aleshkovskii, M. Kh. (1981): Novgorodskii letopisnyi svod kontsa 1220-kh godov. Letopisi i Khroniki. $1980 \operatorname{god}$ (Moscow), pp. 104-112.

Bakulin, P. I. (1973): Astronomicheskii kalendar'. Postoiannaia chast'. Moscow.

Berezhkov, N. G. (1963): Khronologiia russkogo letopisaniia. Moscow.

Bozhilov, I. (1985): Familiiata na Asenevtsi, 1186-1460. Genealogiia i prosopografiia. Sofia.

Brand, Ch. M. (1968): Byzantium Confronts the West, 1180-1204. Cambridge.

Cahen, Cl. (1968): Pre-Ottoman Turkey, 1071-1330. London.

Fedynsky, V. V. (1956): Meteory. Moscow.

Fennell, J. J. (1989): Krizis srednevekovoi Rusi, 1200-1304. Moscow. First edition: Fennell, J. J.: The Crisis of Medieval Russia 1200-1304. London-New York, 1983.

Fine, J. V. A. (1994): The Late Medieval Balkans: A Critical Survey from the Late Twelfth Century to the Ottoman Conquest. Ann Arbor.

Frances, E. (1959): Les relations russo-byzantines au xii siecle et la domination de Galície au basDanube. Byzantinoslavica Vol. 20, No. 1, pp. 50-62.

Gordlevskii, V. (1941): Gosudarstvo sel'dzhukidov v Maloi Azii. Moscow-Leningrad.

Grabler, Fr. (1958): Die Kreuzfahrer erobern Konstantinopel. Die Regierungszeit der Kaiser Alexios Angelos, Isaak Angelos und Alexios Dukas, die Schicksale der Stadt nach der Einnahme sowie das „Buch von den Bildsäulen“ (1195-1206) aus dem Geschichtswerk des Niketas Choniates, mit einem Anhang: Nikolaos Mesarites: Die Palastrevolution des Joannes Komnenos. Graz.

Hoffmann, J. (1974): Rudimente von Territorialstaaten im byzantinischen Reich, 1077-1210: Untersuchungen über Unabhängigkeitsbestrebungen und ihr Verhältnis zu Kaiser und Reich. Munich.

Hrushevs'ky, M. S. (1891): Ocherk istorii Kievskoi zemli ot smerti Iaroslava do kontsa XIV stoletiia. Kiev.

Hrushevs'ky, M. S. (1905): Istoriia Ukrainy-Rusi, Vol. 2. L'viv.

Istoriia na B"lgariia: 14 Vols, Vol. 3: Vtora B"lgarska drzhava, edited by D. Angelov-P. PetrovB. Primov. Sofia, 1982.

Kloss, B. M. (2000): Predislovie k izdaniiu 2000 g. [Preface to the 2000 edition]. In: Nasonov, A. N. (ed.): Polnoe Sobranie Russkikh Letopisei, Vol 3, pp. v-ix.

Kloss, B. M. - Luria, Ia. S. (1976): Russkie letopisi XI-XV vv. In: Zhukovskaia, P. (ed.): Metodicheskie rekomendatsii po opisaniiu slaviano-russkikh rukopisei dlia Svodnogo kataloga rukopisei, khraniashchikhsia v SSSR, Vol. 2/1. Moscow, pp. 78-139.

Kotliar, N. F. (1965): Chy mig Roman Mstislavych khodyty na polovtsiv ranishe 1187 r.? Ukrains'kyi istorychnyi zhurnal No. 1, pp. 117-120. 
Kotliar, N. F. (1989): lz istoricheskogo kommentariia k "Slovu o polku Igoreve" (Kto byl Mstislav). In: Novosel’tsev, A. P. (ed.): Drevneishie gosudarstva na territorii SSSR. 1987 god. Moscow, pp. 43-50.

Kotliar, N. F. (1991): Galitsko-Volynskaia Rus' i Vizantiia v XII-XIII vv. (sviazi real'nye i vymyshlennye). In: Tolochko, P. P. (ed.): Iuzhnaia Rus' $i$ Vizantiia. Kiev, pp. 20-33.

Kotliar, N. F. (2003): Diplomatiia Iuzhnoi Rusi. Saint Petersburg.

Levchenko, M. V. (1956): Ocherki po istorii russko-vizantiiskikh otnoshenii. Moscow.

Litavrin, G. G. (1972): Rus' i Vizantiia v XII veke. Voprosy istorii No. 7, pp. 43-48.

Luria, Ia. S. (1987a): Letopis' Lavrent'evskaia. In: Likhachev, D. S. (ed.): Slovar' knizhnikov i knizhnosti Drevnei Rusi, Vol. 1. Leningrad, pp. 241-245.

Luria, Ia. S. (1987b): Letopis’ Radzivilovskaia [Radziwiłł Chronicle]. In: Likhachev, D. S. (ed.): Slovar' knizhnikov i knizhnosti Drevnei Rusi, Vol. 1. Leningrad, pp. 248-251.

Luria, Ia. S. (1987c): O proiskhozhdenii Radzivilovskoi letopisi'. Vspomogatel'nye istoricheskie distsipliny Vol. 18, pp. 64-83.

Maiorov, A. V. (2014): The Daughter of a Byzantine Emperor - the Wife of a Galician-Volhynian Prince. Byzantinoslavica Vol. 72, Nos 1-2, pp. 188-233.

Maiorov, A. V. (2015a): The Alliance between Byzantium and Rus' before the Conquest of Constantinople by the Crusaders in 1204. Russian History Vol. 42, No. 3, pp. 272-303.

Maiorov, A. V. (2015b): Ecumenical Processes in the mid-13th Century and the Union between Russia and Rome. Zeitschrift für Kirchengeschichte Vol. 126, No. 1, pp. 11-34.

Maiorov, A. V. (2015c): The Cult of St. Daniel the Stylite among the Russian Princes of the Rurik Dynasty. Slavic and East European Journal Vol. 59, No. 3, pp. 345-366.

Maiorov, A. V. (2016): Angelos in Halych: Did Alexios III Visit Roman Mstislavich? Greek, Roman and Byzantine Studies Vol. 56, No. 2, pp. 343-376.

Maiorov, A. V.-Metelkin, E. N. (2016): Die „,deutsche Spur“ in der altrussischen Erzählung über die Einnahme Konstantinopels durch die Kreuzritter. Byzantinische Zeitschrift Vol. 109, No. 2, pp. 809-820.

Miliutenko, N. I. (1996): Vladimirskii velikokniazheskii svod 1205 goda (Radzivilovskaia letopis'). In: Likhachev, D. S. (ed.): Trudy Otdela drevnerusskoi literatury Instituta russkoi literatury (Pushkinskii Dom) Rossiiskoi Akademii nauk, Vol. 49. Saint Petersburg, pp. 36-58.

Moravcsik, Gy. (1983): Byzantinoturcica, Vol. 2. Berlin.

Nasonov, A. N. (1969): Istoriia russkogo letopisaniia XI - nachala XVIII veka. Ocherki i issledovaniia. Moscow.

Nikitin, A. L. (2005): Novgorodskaia Pervaia letopis' i ee izvody. Germenevtika drevnerusskoi literatury (Moscow) Vol. 12, pp. 407-448.

Obolensky, D. (1973): The Relations between Byzantium and Rus' (Eleventh to Fifteenth Century). In: XIII Mezhdunarodnyi kongres istoricheskikh nauk. Moskva, 16-23 Avgust 1970. Report to Congress, Vol. 1/4. Moscow, pp. 202-217.

Obolensky, D. (1998): Vizantiiskoe sodruzhestvo natsii. Shest' vizantiiskikh portretov. Moscow.

Priselkov, M. D. (1996): Istoriia russkogo letopisaniia XI-XVvv. Saint Petersburg.

Rybakov, B. A. (1993): Kievskaia Rus' i russkie kniazhestva XII-XIII vv. Moscow.

Shakhmatov, A. A. (1902): Issledovanie o Radzivilovskoi ili Kenigsbergskoi letopisi. In: Radzivilovskaia ili Kenigsbergskaia letopis', Vol. 2. Saint Petersburg (Obshchestvo liubitelei drevnei pis'mennosti 118), pp. 18-114.

Shakhmatov, A. A. (1904): Ermolinskaia letopis' $i$ Rostovskii vladychnyi svod. Saint Petersburg.

Shakhmatov, A. A. (1938): Obozrenie russkikh letopisnykh svodov XIV-XVI vv. Moscow-Leningrad.

Sviatskii, D. O. (2007): Astronomiia Drevnei Rusi. Moscow. 
Tolochko, A. P. (2005): “Istoriia Rossiiskaia” Vasiliia Tatishcheva: istochniki i izvestiia. Moscow-Kiev.

Tsankova-Petkova, G. (1978): B"'lgariia pri Asenevtsi. Sofia.

Turan, O. (1953): Les souverains seldjoukides et leurs sujets non-musulmans. Studio Islámica (Paris) Vol. 1, pp. 65-100.

Vannier, J.-F. (1986): Les premiers Paléologues: Etude généalogique et prosopographique. In: Cheynet, J. C.-Vannier, J.-F.: Etudes prosopographiques. Paris (Byzantina Sorbonensia 5), pp. $123-187$.

Vásáry, I. (2005): Cumans and Tatars: Oriental Military in the Pre-Ottoman Balkans, 1185-1365. Cambridge-New York.

Zlatarski, V. N. (1994): Istoriia na blgarskata drzhava prez srednite vekove, Vol. 3. Sofia. 